
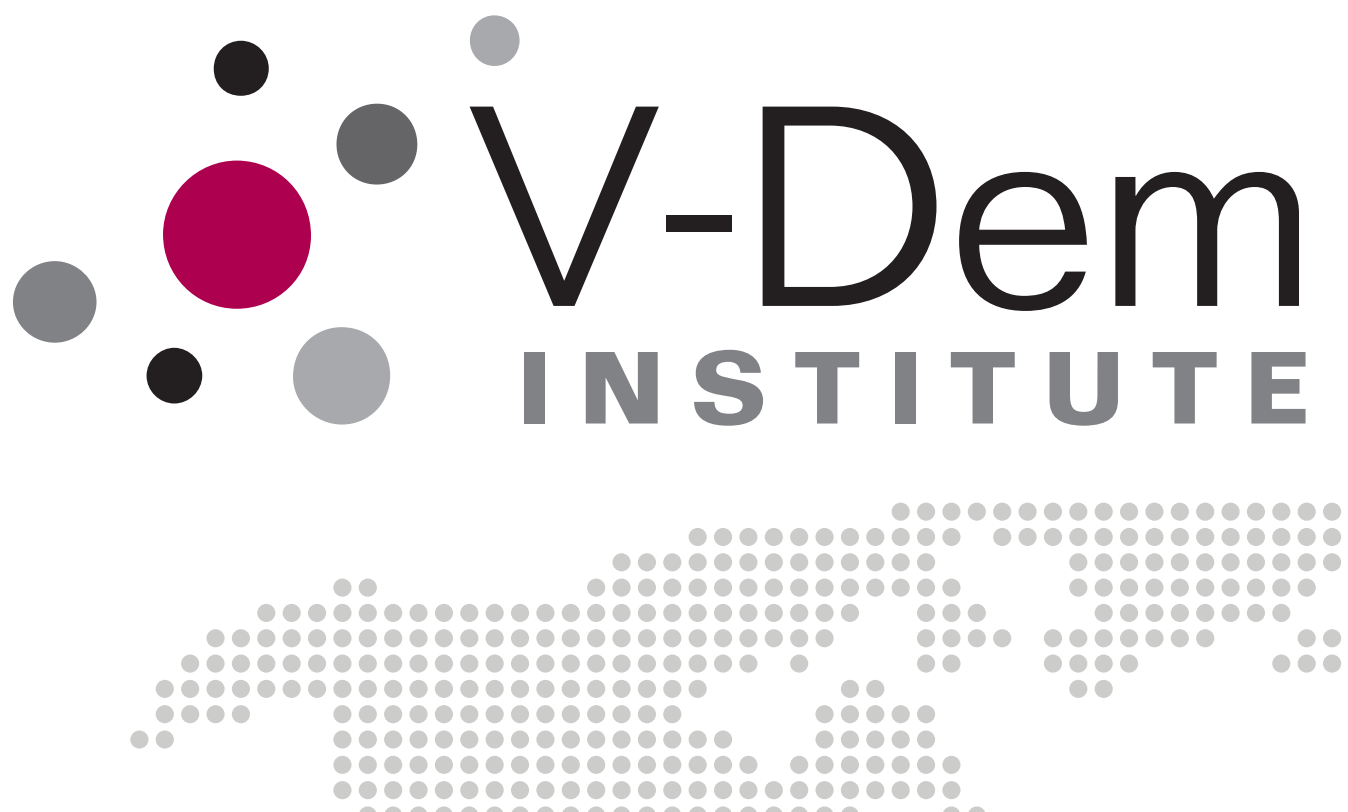

\title{
Democracy and Populism: Testing a Contentious Relationship
}

Saskia P. Ruth-Lovell Anna Lührmann Sandra Grahn מn 100000000000000000

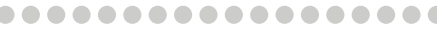
000000000000 1. -

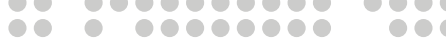

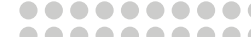
10000000000000000

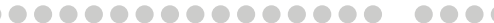

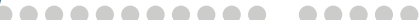

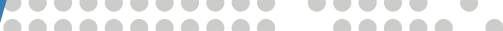

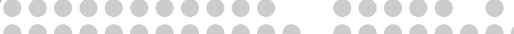

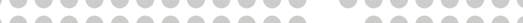

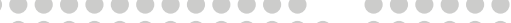

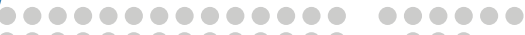
10000000000000

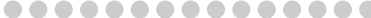

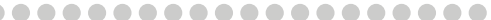

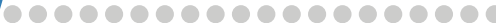

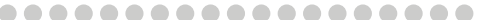

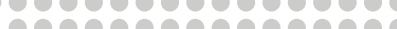
10000000000000

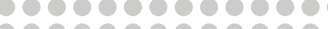


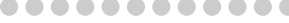

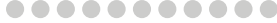

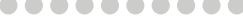

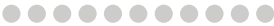

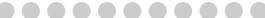
60000000000

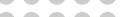
reporosor -

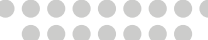

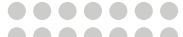
-

- 0000 000 100 웅

更


Varieties of Democracy (V-Dem) is a new approach to conceptualization and measurement of democracy. The headquarters - the V-Dem Institute - is based at the University of Gothenburg with 17 staff. The project includes a worldwide team with six Principal Investigators, 14 Project Managers, 30 Regional Managers, 170 Country Coordinators, Research Assistants, and 3,000 Country Experts. The V-Dem project is one of the largest ever social science research-oriented data collection programs.

Please address comments and/or queries for information to:

V-Dem Institute

Department of Political Science

University of Gothenburg

Sprängkullsgatan 19, PO Box 711

SE 40530 Gothenburg

Sweden

E-mail: contact@v-dem.net

V-Dem Working Papers are available in electronic format at www.v-dem.net.

Copyright (C) 2019 by authors. All rights reserved. 


\title{
Democracy and Populism: Testing a Contentious Relationship*
}

\author{
Saskia P. Ruth-Lovell \\ GIGA German Institute of Global and Area Studies \\ Anna Lührmann \\ University of Gothenburg \\ Sandra Grahn \\ University of Gothenburg
}

\footnotetext{
* This research was supported by Vetenskapsrådet [grant number 2018-016114], PI: Anna Lührmann and European Research Council, Grant 724191, PI: Staffan I. Lindberg, V-Dem Institute, University of Gothenburg, Sweden as well as by internal grants from the Vice-Chancellor's office, the Dean of the College of Social Sciences, and the Department of Political Science at University of Gothenburg. We thank participants of the 2018 DVPW congress and of Lüneburg as well as Gothenburg University seminars for their valuable feedback to earlier versions of this paper and Lena Günther for her skillful research assistance.
} 


\begin{abstract}
The phenomenon of populism and its relationship with modern democracy has gained considerable attention in recent years. This paper aims at advancing our understanding of how populism affects different models of democracy and tests the proposed arguments empirically. Building on the large scholarly literature on populism and democracy, we take stock of existing arguments and theorize which democratic models may be affected by populism in a positive or a negative way. Moreover, we move beyond the normative debate and analyse the effect of populism in power on different models of democracy empirically. We do so by merging data on populist governments in Europe and Latin America from the 1995 until today with the Varieties of Democracy data set, which enables us to capture the relationship between populism and different democratic models in these regions.
\end{abstract}




\section{Introduction}

Populism has moved to the centre of public and scholarly attention in recent years. However, populism is not a new phenomenon. Populist forces have been successful in elections in diffrent regions such as Europe, Latin America, India and East Asia even before the current populist surge in western democracies (see contributions in Rovira Kaltwasser et al., 2017). In consequence, populist forces gained and maintained representative offices in both new and old democracies and took over government responsibility in some of them (e.g. Albertazzi \& McDonnell, 2008; Conniff, 2012; Mudde \& Rovira Kaltwasser, 2012b). Populists challenge established norms and political actors in modern democratic systems. However, it is contested in the academic literature how the rise of populist forces to public office affects the quality of democratic regimes (see, among others, Canovan, 1999, 2002; Mény \& Surel, 2002; Rovira Kaltwasser, 2012). On the one hand, scholars most frequently point out that populism undermines the particular combination of liberal democracy, most importantly its emphasis on horizontal accountability (e.g. Mudde \& Rovira Kaltwasser, 2012a; Plattner, 2010). On the other hand, some researchers ascribe populism the potential to strengthen political participation and improve the representative link between politicians and citizens due to its emphasis on vertical mechanisms of democratic accountability such as direct democracy or elections (e.g. Canovan, 1999; Laclau, 2005; Mény \& Surel, 2002).

Recently, researchers started to test their theories and assumptions about the relationship between populism and democracy empirically. In doing so, scholars have focused their attention on specific aspects of democracy and contributed either to the conclusion that populism is rather a threat (Houle \& Kenny, 2018; Huber \& Schimpf, 2016; Kenny, 2019; Ruth, 2018) or a corrective potential for representative democracy (e.g. Huber \& Ruth, 2017; Ruth \& Welp, 2018; Ruth \& Hawkins, 2017). However, what is missing is a syntheses and systematic comparison of the ambivalent impact of populism on different aspects of democracy. Our paper, hence, addresses two lacunae in the literature by assessing the relationship between populism and diff $t$ models of democracy within an overarching framework.

To overcome the regional segmentation within the field of populism studies, we provide a cross-regional comparative analysis of the relationship between populism in power and different models of democracy. We measure both phenomena in two regions which have been particularly affected by the rise of populism to power: Europe and Latin America.1 To identify populist governments we build on three data sets; two on European cabinets (Huber \& Ruth, 2017; Huber

\footnotetext{
${ }^{1}$ Note that the recent rise of populism is mainly a European phenomenon, while the Latin American region has a much longer experience with the phenomenon
} 
\& Schimpf, 2016, 2017) and parties (Rooduijn et al., 2019) and one on Latin American presidential terms (Ruth, 2018).

The paper is structured as follows: in the theory section, we provide a short synthesis of populism studies as well as democratic theory. We proceed with a discussion on different models of democracy and connect them to several populist ideas emphasized in the populism literature to derive at a set of testable hypotheses. The next section introduces the data and methods used and the methodological considerations behind our estimation procedures. In the following sections, we discuss our findings and provide concluding remarks as well as an outlook on the way forward.

\section{Towards a Multi-Dimensional Theory of Populism and}

\section{Democracy}

For a long time, disagreement over conceptualization hampered the accumulation of knowledge about the causes and consequences of populism. Recently, however, a tentative consensus around an ideational definition of populism emerged in the fi of political science (e.g. Hawkins \& Rovira Kaltwasser, 2017; Mudde \& Rovira Kaltwasser, 2018). Researchers adhering to the ideational approach usually agree on three core ideas that form the necessary defining characteristic of populism: people-centrism, anti-elitism, and an antagonistic relationship between the "virtuous people" and the "corrupt elite" (e.g. Hawkins, 2010; Mudde, 2004; Rooduijn, 2014a).2 In line with the ideational approach, we define populism as a set of ideas "that considers society to be ultimately separated into two homogeneous and antagonistic groups, 'the pure people' versus 'the corrupt elite', and which argues that politics should be an expression of the volontée génrale (general will) of the people" (Mudde, 2004, 543, italics original).

Note that some authors refer to the anti-pluralist nature of populism as a defining attribute (Galston, 2019; Müller, 2016). Two ideas within the ideational approach are closely associated with anti-pluralism: (1) the portrayal of the people as a homogeneous group and (2) the Manichean worldview, which results in the vilification of opponents. We opt here to use these more specific

\footnotetext{
2 Disagreement about the nuances within the ideational approach explain the different labels re- searchers use to reference it, for example as a thin-centred ideology (Mudde, 2007), a political discourse (De Cleen \& Stavrakakis, 2017), or a discursive frame (Aslanidis, 2016) - to name just a few. Moreover, disagreement also remains with respect to its relationship with medium-range conceptualizations of populism, like the political-strategic approach and the cultural approach for which populist ideas are only one of several necessary conditions of populism (Weyland, 2017; Roberts, 2017; Ostiguy, 2017; In- glehart \& Norris, 2017). Economists, on the other hand, have not yet engaged in a similar endeavour of conceptual clarification, which hinders the accumulation of knowledge across time and space as well as the comparability of insights across disciplinary divides (Aslanidis, 2017; Rodrik, 2018).
} 
attributes to define populism, rather than the negation of its opposite concept. Note also that the consequences of particularly the first listed attribute of populism for pluralism are highly dependent on the inclusionary or exclusionary definition of the people, i.e. their ideological leaning (see Mudde \& Rovira Kaltwasser, 2013), which we discuss in more detail below.

This definition is well equipped for the comparative analysis of populism across time and space (Hawkins, 2010; Hawkins et al., 2019; Mudde \& Rovira Kaltwasser, 2012b). Furthermore, it does not preclude the specification of subtypes of populism through the combination of populist ideas with other ideological, organizational, or personalistic elements (March, 2007; Mudde, 2007; Roberts, 2018; Weyland, 2017). Most importantly, the ideational approach lends itself well to measure populism in systematic (both qualitative and quantitative) ways allowing researchers to test causal arguments (Aslanidis, 2018; De Cleen \& Stavrakakis, 2017; Hawkins et al., 2019).

Democracy is an even more contested concept than populism. Until today, there is no consensus on what democracy means other than the vague idea of "rule by the people" (Collier \& Levitsky, 1997; Munck, 2016). Democratic theorists, however, indicate that there are many different ways in which "rule by the people" can be institutionalized, depending on which principles and functions are emphasized. A simultaneous maximization of all desirable democratic principles and functions is impossible (e.g. Giebler \& Merkel, 2016). Therefore, democratic theorists and empirical democracy scholars alike usually refer to different patterns, models or varieties of democracy (Coppedge et al., 2011; Held, 2010; Lijphart, 1999). Here, we follow the VDem approach of distinguishing between fi e diff t ideas of democracy; namely the electoral, liberal, participatory, deliberative and egalitarian models of democracy (Coppedge et al., 2015).

The most basic conception of democracy is the model of electoral democracy. In its minimalist expression, it refers to the procedures of competition between political elites for votes (Munck \& Verkuilen, 2002; Schumpeter, 1950). Conceptualizations that are more extensive add factors that ensure the meaningfulness of elections as instruments of democracy, like the protection of freedom of expression and association (e.g. Dahl, 1956, 1971). This more ambitious notion of electoral democracy, which Robert Dahl has labelled as "polyarchy", is in the focus of our study here.

The most prominent model - today - is probably the model of liberal democracy. In addition to meaningful elections, this model highlights the need to safeguard individual liberties and rights from infringement by ruling elites, i.e. the protection against a potential tyranny of the majority (Dahl, 1989; Zakaria, 1997). Liberal democracies are characterized by strong constitutionalism, e.g. by the constitutional protection of civil liberties, institutional checks on the government, and the rule of law (O’Donnell, 2003; Plattner, 1999). The liberal model takes a 
critical view on majority rule and highlights the need to safeguard democracy institutionally from overly powerful governments.

The participatory model of democracy, on the other hand, is far less concerned with majority rule to identify the will of the people as long as citizens participate actively in the political process (Grofman \& Feld, 2013; Pateman, 2012). It emphasizes the value of self- government and citizen participation beyond elections (Fung \& Wright, 2003; Pateman, 1976). In addition to civil society participation, it focuses on instruments of direct as well as local and regional democracy.

While the electoral and participatory models emphasize the input legitimacy of democratic systems, the two following models shift their view towards the throughput and output side of the democratic process (Scharpf, 1999; Schmidt, 2013). The deliberative model of democracy focuses on the pursuit of the public good through respectful dialogue and public reasoning (e.g. Dryzek, 2010; Fishkin, 1991; Habermas, 1992). Citizens and elites need to be open-minded and take informed decisions after exchanging arguments and discuss different views on the issue at hand (see Saward, 2000). Finally, the model of egalitarian democracy highlights the principle of equality and that all citizens need to have the same opportunities to participate in the democratic process and make them- selves heard (Dahl, 1989). As such this model also considers a more active role of the state in the economy, combating the unequal distribution of resources which may lead to unequal political power (see Saward, 1998; Shefner, 2013).

Since its beginning, the normative theoretical debate on populism has been intimately connected to the study of democracy (e.g. Canovan, 1982; Laclau \& Mouffe, 1985; Urbinati, 1998). Several arguments in the literature refer to the ambiguous relationship between these two concepts (e.g. Mény \& Surel, 2002; Rovira Kaltwasser, 2012). This ambiguity can be traced back to tensions between core ideas of populism and different conceptions of democracy, such as between "the will of the people" and representative government (see Mair, 2009; Urbinati, 1998) or popular sovereignty and liberal checks and balances (e.g. Canovan, 2002; Ochoa Espejo, 2012). In the following sections we will disentangle the connections between these two multi-dimensional concepts.

\section{The Ambiguous Relationship between Populism and Democracy}

Populist forces often come to political power with an agenda of institutional change, directed at the renewal and transformation of representative democracy (Decker, 2011; Dubiel, 1986; Levitsky \& Loxton, 2013; Ruth, 2018). For instance, the former Peruvian president Alberto 
Fujimori proclaimed himself as the "architect of modern democracy". In 2017, decades after his autogolpe in 1992, he justified his move to dissolve parliament as a step to "safeguard democracy"; adding that "in order to make Tortillas you have to break eggs". The Venezuelan president Hugo Ch'avez portrayed himself as a fighter for "revolutionary democracy" and human rights. ${ }^{5}$ Evo Morales sees himself has the "democratic voice of Bolivia". "In Hungary, Victor Orba'n propagates that "a democracy does not necessarily have to be liberal. Just because a state is not liberal, it can still be a democracy". ${ }^{7}$

It is no surprise, that researchers have also debated the affinity between populism and authoritarianism (Inglehart \& Norris, 2017; Levitsky \& Loxton, 2013; Müller, 2016). Among European scholars it is mainly the populist radical right which is associated with authoritarian tendencies (on a critical review see Bonikowski, 2017; Mudde, 2007; Rooduijn, 2014b), while Latin American scholars associate leftist populists with the rise of competitive authoritarian regimes (Levitsky \& Loxton, 2013). We argue here, that to study the consequences of populism on different democratic models it is important to distinguish different phases of populist success. While populists often gain public office with a promise of reforming, improving, and deepening democracy, once in power, the same populists may erode core democratic institutions to maintain power over time (Chesterley \& Roberti, 2018; Ruth, 2018). Hence, although (core) populist ideas per se are not undemocratic, they may be used to undermine pluralism - in particular when combined with different exclusionary or nationalist ideologies - and enable the election of authoritarian-leaning leaders into public office (Bonikowski, 2017, pp. 189-191; Hawkins, 2010, pp. 29-33).

The study of populism, recently, experienced renewed attention among empirical researchers aiming at measuring populism systematically and testing different theoretical arguments about its causes beyond in-depth case studies and small-N designs (see Hawkins et al., 2019). More specifically, researchers also started to test the various consequences of populism (both in opposition and in power) on democratic norms and institutions. On the one hand, scholars identified negative implications of populism for democracy's procedural and liberal elements (Batory, 2016; Chesterley \& Roberti, 2018; Houle \& Kenny, 2018; Huber \& Schimpf, 2016; Ruth, 2018). A few studies, on the other hand, show a positive impact of populism on

\footnotetext{
${ }^{3}$ https://peru21.pe/politica/alberto-fujimori-25-anos-autogolpe-arquitecto-democracia-moderna-71652.

${ }^{4}$ https://elcomercio.pe/politica/actualidad/fujimori-desperdicio-oportunidad-consolidar-democracia-421175.

${ }^{5}$ https://www.telesurtv.net/news/Las-frases-que-inmortalizaron-a-Hugo-Chavez-201603050013.html.

${ }^{6}$ https://www.theguardian.com/world/2016/feb/22/bolivia-evo-morales-president-national-referendum-fourthterm.

${ }^{7}$ Orbán in July 2014 as quoted by Plattner $(2019,9)$
} 
democratic representation and participation (Caramani, 2017; Huber \& Ruth, 2017; Ruth \& Hawkins, 2017). However, this fragmentation in the analysis of the impact of populism on democracy precludes the evaluation of an overall effect of populism in power on different models of democracy. Therefore, in this paper, we study both the potential negative and positive consequences of populism in power for different models of democracy within one overarching framework.

In order to highlight the relevance of the relationship between populism and different models of democracy further, Figure 1 contrasts two well-known examples of populism in both regions under study here: Venezuela (Figure 1a) and Hungary (Figure 1b). The spider diagrams illustrate how the fi e models of democracy fare before and during populist rule in these countries. 8 In both of them a decline across several aspects of democracy can be observed.

\section{Figure 1: V-Dem Democracy Indices for Venezuela and Hungary}

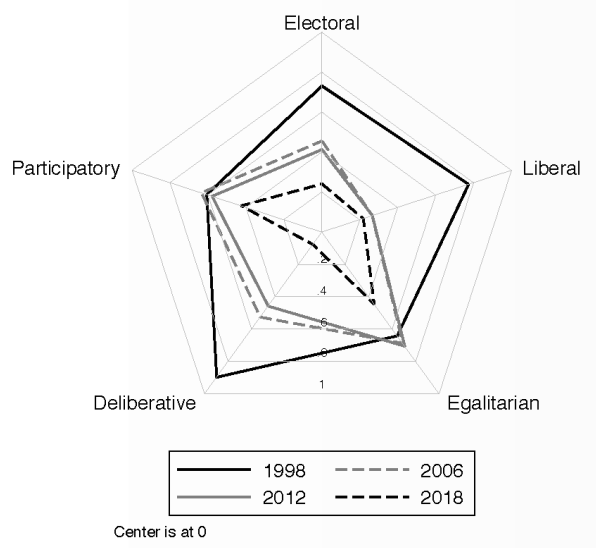

(a) Venezuela

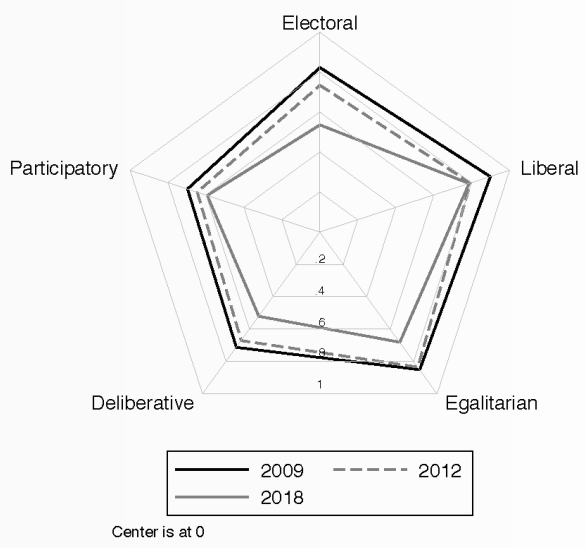

(b) Hungary

In Venezuela, the liberal, electoral and deliberative models of democracy dropped from relatively high levels of democracy in the year before the far-left populist Hugo Chávez took office (1998) to relatively low levels in 2012, his last year in office. The electoral and deliberative models of democracy dropped even further during Nicolas Maduro's time in office from 2013 onwards. It is noteworthy, that Venezuela did neither improve substantially in terms of participatory and egalitarian aspects of democracy. While they fi improved slightly - potentially due to an increased emphasis on referenda and the introduction of social programmes under Chávez - they dropped during the most recent fi e years under Maduro; in particular with respect to the egalitarian index.

\footnotetext{
${ }^{8}$ Based on V-Dem data (Coppedge, Gerring, Knutsen, Lindberg, Skaaning, et al., 2019). For a detailed description of the data and sources see section "Data and methods" further below.
} 
Hence, while the drop in liberal aspects of democracy occurred already during the five years of Chávez' rule - turning the regime into the direction of competitive authoritarianism, Maduro further entrenched this trend (Levitsky \& Loxton, 2013).

Figure $1 \mathrm{~b}$ illustrates the development in Hungary over the course of the second far-right populist government under Viktor Orbán. It shows that all fi e models of democracy have declined since 2009 (the year before Orbán took office). This fits to Bogaards (2018) assessment that the Hungarian democracy erodes across all models of democracy due to measures such as restrictions of media pluralism, the rule of law and extensive gerrymandering. After initial hesitation, Orbán has embraced the idea of "illiberal democracy" in order to justify his policies against nontraditional family structures and immigration (Plattner, 2019). Consequently, on May 17th 2017, the European Parliament stated in a resolution that the current situation in Hungary represents a clear risk of a serious breach of the values referred to in Article 2 of the Treaty on the European Union, which include "respect for democracy, the rule of law and human rights".99

As these illustrative cases indicate, it is highly relevant to theorize and empirically test the multi-dimensional relationship between populist rule and diff $t$ aspects of democracy. These two examples also show, that the consequences of populist rule travel across contexts, which is why we need to investigate this phenomenon beyond national and regional peculiarities. However, they also suggest that populism in power may affect different models of democracy differently, indicating that there may be moderating factors at play causing this variation. For this purpose, the next section proposes a multi- dimensional theory of the relationship between populism and democracy.

\section{Populist Ideas and Different Models of Democracy}

In order to disentangle the impact of populism in power on various models of democracy we build our arguments on the ideational approach (see above). Focusing on the ideas central to the populist appeal enables us to theorize on and later test the relationship between populism and democracy (see Hawkins et al., 2019). Above, we have identified three broad ideas central to the ideational approach to populism: people-centrism, anti- elitism and an antagonistic, Manichean worldview. Here, we further disentangle the people-centric notion of populism into three subcomponents (e.g. Ochoa Espejo, 2012; Canovan, 2002): First, the emphasis on popular sovereignty implies that citizens should authorize all major political decisions. Second, the notion of the will

\footnotetext{
9 9EP Committee on Civil Liberties, Justice and Home Affairs: http:/ / www.europarl.europa.eu/sides/getDoc.do?type=REPORT\&mode=XML\&reference=A8-20180250\&language $=\mathrm{EN} \#$ title 3 .
} 
of the people (volonté general) suggests that a unified will of the people exists, which negates not only that citizens may have divergent interests and views but also challenges the role of intermediary actors such as political parties and the media in representing such divergent interests. Third, exclusionary populists emphasize the homogeneity of the people and have a narrow understanding of who belongs to this in-group. In addition to these three people-centric ideas of populism, the anti-elitist notion of populism leads to a distrust in elites. Finally, the idea of an antagonistic, Manichean worldview entails a moralistic and simplistic contrast of politics as "us" (good) versus "them" (bad), which justifies the vilification of opponents (elites as well as their supporters) (Hawkins, 2010). We expect these five populist ideas to have divergent and partly ambiguous effects on different models of democracy, which we discuss one by one below. We summarize our expectations in Table 1.

The association between populist ideas and electoral democracy is particularly ambiguous: On the one hand, the people-centrism of the populist appeal - with its focus on popular sovereignty - puts an emphasis on vertical mechanisms of accountability, most importantly, elections (Canovan, 1999; Ochoa Espejo, 2015). On the other hand, due to their antagonistic appeal (Manichean worldview) populist forces are inclined to vilify opponents - associating them with the "corrupt elite" - and to portray themselves as the only legitimate interpreter of the will of the people, which may serve as a justification to hollow out electoral procedures and to skew the electoral playing field (Hawkins, 2010; Levitsky \& Loxton, 2013). Based on these arguments we would expect an ambiguous relationship between populism and electoral democracy. A first descriptive look at our data, however, paints a rather worrisome picture. ${ }^{10}$

Figure 2 shows the change in the V-Dem Electoral Democracy Index (EDI) during the time in office of populist presidents or prime ministers (y-axis), comparing the level of the EDI in the year before a populist came to power to the level of EDI in their last year in office. Three observations stick out: First, during most populist tenures (20 out of 30), the EDI did not change substantially (+/- 5 percent or 0.05 points on the EDI scale). Second, during ten populist tenures, however, the EDI dropped substantially: under Alberto Fujimori (Peru 1990-2000), Boyko Borisov (Bulgaria 2009-2013 and 2014- 2018), Hugo Ch'avez (Venezuela 1999-2013), Rafael Correa (Ecuador 2007-2017), Mateusz Morawiecki (Poland 2017-ongoing), Evo Morales (Bolivia 2006-ongoing), Viktor Orbán (Hungary 2010-ongoing), and Daniel Ortega (Nicaragua 2007ongoing). Third, the EDI did not substantially increase during any populist tenure.

\footnotetext{
${ }^{10}$ We provide a detailed description of the data in the empirical part of this paper.
} 
Figure 2: Changes in V-Dem Electoral Democracy Index during Populist Time in Office in Latin America and Europe (1995-2018)

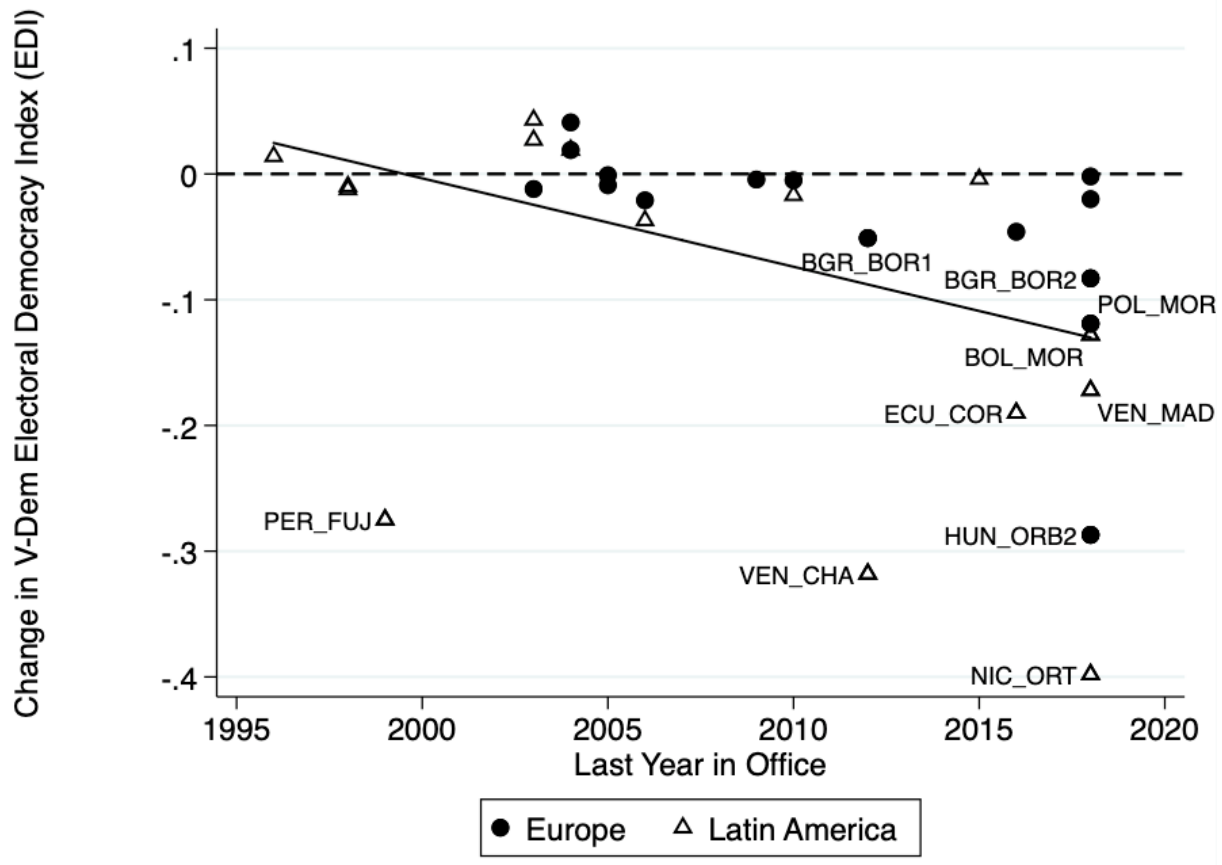

Note: A list with tenure IDs is provided in Table S1 in the supplementary material.

Based on the literature, a more clear-cut negative relationship can be argued for with respect to the liberal model of democracy. Theoretically, populist ideas value vertical accountability overall and at the same time advocate to mistrust political elites, which are the core actors within horizontal accountability mechanisms. Several studies showed that populist governments engaged in the erosion of horizontal accountability mechanisms, especially, if traditional elites played a central role in them (Houle \& Kenny, 2018; Ruth, 2018). Moreover, while liberalism’s biggest fear is the tyranny of the majority, populism actually favours majoritarianism as a means to identify the will of the people (Grofman \& Feld, 2013; Plattner, 1999).

Populism has been associated with a radical democratic model based on a plebiscitary style of participation that runs counter to liberal democratic institutions, especially parliaments, which often are the nucleus of power of traditional elites (Laclau \& Mouffe, 1985; Rovira Kaltwasser, 2012, 2014). Hence, we expect populism to be positively associated with the participatory model of democracy. References to the people-centrism component of populism also figure prominent in recent theoretical and empirical studies on the impact of populism on participatory democracy (Bowler et al., 2007; Rhodes- Purdy, 2015). Ruth \& Welp (2018), for example, show in their study that the expansion of direct democratic mechanisms in the region is significantly related to the 
presence of populist forces in government in these countries.

Less studied, however, is the impact of populism on the notions of deliberative or egalitarian democracy. We argue here that the antagonistic relationship between 'the corrupt elite' and 'the good people' inherent in the populist discourse - i.e. the Manichean world- view - stands in sharp juxtaposition to the logic of deliberation (Hawkins, 2010; Laclau, 2005). Moreover, as part of the people-centrism component, populists often recur to "the people" as a homogeneous group with an identifiable common will, as such, populism has an anti-pluralist view of the people (Mudde, 2004; Mudde \& Rovira Kaltwasser, 2012a; Plattner, 1999, 2010). Finally, populist ideas align well with the egalitarian notion of democracy, most importantly, with respect to their focus on output legitimacy. Both populism and egalitarianism are concerned with the potential distortions of political out- puts if economic inequalities translate into political inequalities (Foweraker, 2018). These arguments would lead us to expect a negative relationship between populism and deliberative democracy and a positive relationship between populism and egalitarian democracy.

\section{Strong versus Weak Democracy}

With respect to the impact of populism in power on democracy, a moderating factor that has been highlighted to safeguard democracy against erosive tendencies of populist governments is the degree of democratic quality prior to their rise to power (Mudde \& Rovira Kaltwasser, 2012a; Schedler, 1998). Well-developed democratic institutions and norms constrain the ability of governments to erode them (Keane, 2009; Levitsky \& Murillo, 2013; O’Donnell, 1996). Thus, "populists will be more effective when democracy is weak; or to put it in another way, the strength of democracy influences the depth of the populism's impact on democracy" (Mudde \& Rovira Kaltwasser, 2012a, 22-23). Hence, we assume that the impact of populist governments on each democratic model is moderated by its initial quality.

\section{Exclusionary versus Inclusionary Populism}

Moreover, one core element of populism further adds nuances to the picture. Although all populist forces portray "the people" as a homogeneous group, some populists on the right side of the ideological spectrum exclude large parts of the population from their demarcation of the demos, while inclusionary variants of populism on the left side of the political spectrum tend to include larger segments of the population in this term (Mudde \& Rovira Kaltwasser, 2013; Ochoa Espejo, 2015). For a long time research on populism has been confined to intra-regional studies, and due to the dominance of right- 
wing populism in Europe and left-wing populism in Latin America, this regional bias led to another bias with respect to the role ideological variants play (Aslanidis, 2017; Mudde \& Rovira Kaltwasser, 2018). However, with the comparative turn in populism studies, researchers began to engage in cross-regional comparisons and highlighted the potential moderating factor of the ideological leaning of populist forces and their impact on democracy. Empirical findings, however, remain scarce and inconclusive (Huber \& Ruth, 2017; Kenny, 2019).

Based on the set of populist ideas elaborated in the previous section, we argue that the relationship between exclusionary and inclusionary variants of populism and the deliberative and egalitarian model of democracy should be different. While the idea of the homogeneity of the people alludes to the equalizing potential of populism, how inclusive or exclusive populist forces are depends on their appeal to different groups (Mudde \& Rovira Kaltwasser, 2013; Ochoa Espejo, 2015; Rooduijn \& Akkerman, 2017). While far- right populists tend to define the people in a narrow exclusivist way, far-left populists are considered to be more inclusive. Thus, we expect far-left populists in power to reinforce the positive impact of populism on egalitarian notions of democracy, compared to centrist or far-right populists. At the same time, we expect far-right populists to exacerbate the negative impact on deliberative aspects of democracy compared to centrist or far-left populist, due to their use of exclusionary rhetoric.

Overall we expect:

Hypothesis 1: Populists in power are likely to have mixed effects on the electoral model of democracy. Hypothesis 2: Populists in power are likely to have negative effects on the liberal model of democracy. Hypothesis 3: Populists in power are likely to have negative effects on deliberative models of democracy. Hypothesis 4: Populists in power are likely to have positive effects on participatory models of democracy. Hypothesis 5: Populists in power are likely to have positive effects on egalitarian models of democracy.

We also formulate the following conditional expectations:

Hypothesis 6: The lower the quality of a specific model of democracy is, the stronger the bypothesized effect of populist in power is on the respective model of democracy.

Hypothesis 7a: Far-right populists in power are likely to further increase the negative effect on deliberative models of democracy compared to other populist governments.

Hypothesis 7b: Far-left populists in power are likely to increase the positive effect on egalitarian models of democracy compared to other types of populist governments.

Table 1 summarizes our notions on the heterogeneous effect of populist ideas on different models of democracy. 
Table 1: Hypotheses Overview

\begin{tabular}{|c|c|c|}
\hline Populist Idea & Models of Democracy & $\begin{array}{c}\text { Assumed } \\
\text { Association }\end{array}$ \\
\hline $\begin{array}{l}\begin{array}{l}\text { Popular sovereignty } \\
\text { (people-centrism) }\end{array}\end{array}$ & $\begin{array}{l}\text { Electoral Democracy (H1) } \\
\text { Liberal Democracy (H2) } \\
\text { Participatory Democracy (H4) }\end{array}$ & $\begin{array}{l}+ \\
- \\
+\end{array}$ \\
\hline $\begin{array}{l}\text { Will of the people } \\
\text { (people-centrism) }\end{array}$ & $\begin{array}{l}\text { Liberal Democracy (H2) } \\
\text { Deliberative Democracy (H3) } \\
\text { Participatory Democracy (H4) } \\
\text { Egalitarian Democracy (H5) }\end{array}$ & $\begin{array}{l}- \\
- \\
+ \\
+\end{array}$ \\
\hline $\begin{array}{l}\text { Distrust in elites } \\
\text { (anti-elitism) }\end{array}$ & Liberal Democracy (H2) & - \\
\hline $\begin{array}{l}\text { Manichean worldview } \\
\text { (antagonistic appeal/ vilifying } \\
\text { opponents) }\end{array}$ & $\begin{array}{l}\text { Electoral Democracy (H1) } \\
\text { Deliberative Democracy (H3) }\end{array}$ & $\begin{array}{l}- \\
-\end{array}$ \\
\hline $\begin{array}{l}\text { Homogeneity of the people } \\
\text { (people-centrism) } \\
\text { - Exclusionary (far-right) } \\
\text { - Inclusionary (far-left) }\end{array}$ & $\begin{array}{l}\text { Deliberative Democracy }(\mathrm{H} 7 \mathrm{a}) \\
\text { Egalitarian Democracy }(\mathrm{H} 7 \mathrm{~b})\end{array}$ & $\begin{array}{l}- \\
+\end{array}$ \\
\hline & $\begin{array}{l}\text { Quality of each model of democracy } \\
\text { (H6) }\end{array}$ & + \\
\hline
\end{tabular}

\section{Data and methods}

Empirical studies testing the relationship between populism and democracy have been dominated by an exclusive focus on the partial effect of populism on different democratic principles or function. Additionally, empirical research on populism has been characterized by a nearly perfect regional segmentation of the field and a focus on region-specific subtypes of populism (e.g. left-wing populism in Latin America versus the populist radical right in Europe) (Aslanidis, 2017; Mudde \& Rovira Kaltwasser, 2018). This underlines the relevance of the recent plea by Mudde \& Rovira Kaltwasser (2018), urging researchers in the field of populism studies to leave their 'comfort zone' and engage in more cross-regional interactions to foster the integration of the field and the accumulation of knowledge on the topic. Therefore, this paper relies on a cross-regional research design, comparing new democracies in Latin America and Central Eastern Europe to more established democracies in Western Europe.

\section{Operationalization}

\section{Quality of Different Models of Democracy}

In order to assess the relationship of populism with different democratic models, we use 
the expert-coded data from the Varieties of Democracy Project (V-Dem, Coppedge, Gerring, Knutsen, Lindberg, Skaaning, et al., 2019) to capture our dependent variables. V-Dem provides more than 350 indicators on various aspects of democracy for 182 countries from 1900 to 2018. A sophisticated protocol for the recruitment of typically five experts per data point and the aggregation of their responses enhances the reliability of the expert-coded data (Coppedge, Gerring, Knutsen, Lindberg, Teorell, et al., 2019; Pemstein et al., 2018). V-Dem constructs socalled High-Level Indices (HLIs) based on its indicators in order to capture the level of electoral, liberal, participatory, egalitarian and deliberative aspects of democracy. ${ }^{11}$ All indices range from 0 (not at all democratic) to 1 (fully democratic).

- The V-Dem Electoral Democracy Index (EDI) captures key electoral institutions of democracy for leaders and officials to be held accountable and responsive towards the people, and achieving a fundamental principle of democracy: The sovereignty of the people. The EDI comprises six components that together cover the central electoral aspects of democracy: The clean election index, the freedom of association index, the alternative sources and freedom of association index, the suffrage indicator, and the elected officials' index.

- The V-Dem Liberal Component Index (LCI) captures the central liberal aspect of democracy that ensures citizens' and minority groups' protection from the tyranny of the state and of the majority, an important element of a democratic state. It includes the equality before the law and individual liberty as well as judicial and legislative constraints on the executive.

- The V-Dem Participatory Component Index (PCI) captures additional mechanisms (beyond elections) through which citizen can input their preferences into to democratic process. It is based on four sub-indices on civil society participation, direct popular vote, local and regional government.

- The V-Dem Deliberative Component Index (DCI) is based on fi e indicators on the behaviour of political elites capturing reasoned justification, common good orientation, respect for counterarguments, the range of consultation, and lastly, engagement of society.

\footnotetext{
11 These HLIs come in two variants: The component indices, which focus only the respective aspect of democracy (e.g. deliberation) and the democracy indices, which include both the respective component index and the Electoral Democracy Index. Thus, the democracy indices reflect the notion that without vertical accountability a political regime does not qualify as a democracy; no matter how well it fares in terms of egalitarianism or other aspects of democracy (Coppedge et al., 2015). However, here we are interested in gaining a clear picture about how populism affects different aspects of democracy - setting aside such normative considerations. Therefore, we use the component indices for all non-electoral aspects of democracy. The component indices are aggregated based on conceptual arguments following both a logic of family resemblance and necessary conditions (Coppedge et al., 2015).
} 
This index reflects that democratic decision-making should demonstrate public reasoning motivating policy decisions with a focus on the larger common good rather than using emotional appeals, coercion, or solidarity attachments.

- Egalitarian notions of democracy emphasize that an unequal society obstructs democratic mechanisms such as participation and representation by failing to achieve an equal distribution of protection and resources. The V-Dem Egalitarian Component Index (ECI) capture this dimension of democracy by including indices on equal protection, equal access and distribution of resources.

We include the level of each of these indices at $(\mathrm{t} 0)$ as the dependent variables in our models below.

\section{Measuring Populism}

Since the arguments in the theoretical part trace back to the underlying ideas of the populist appeal, our populism measure builds on the ideational approach to distinguish populist from nonpopulist governments. Systematic data on populist governments is scarce. However, we build on three data sets that have recently become available, each capturing populism as a dichotomous variable. First, for Latin America, we rely on the presidential terms data set from Ruth (2018) which follows a two-step procedure to identify populist governments (i.e. presidents that came into office using a populist discourse) based on a combination of both a qualitative literature review and expert validation. This data set covers 18 countries within the period from 1980-2018.

Second, for the coding of populist governments in Western and Central Eastern Europe we combine two data sources. In order to identify which European party qualifies as populist, we utilize Rooduijn et al. (2019) recent comprehensive account, which is based on expert assessments of all political parties which gained at least 2 percent of the vote share in 30 European countries from 1995-2018, and was peer-reviewed by over 30 academics. We combine this data with data provided by Huber \& Schimpf $(2016,2017)$ and Huber \& Ruth (2017) in order to identify when prime ministers affiliated with these parties were in office. ${ }^{12}$

Merging these datasets leaves us with a cross-regional coverage of 24 years (1995-2018), including 289 separate tenures - the period over which one president or prime minister served consecutively - in 47 countries. Overall, our sample includes 28 populist and 246 non-populist presidents or prime ministers ruling for - on average - 5.9 years (ranging from as low as one to 18

\footnotetext{
${ }^{12}$ Note Huber \& Schimpf $(2016,2017)$ and Huber \& Ruth (2017) also provide an assessment on populist vs. nonpopulist parties in their dataset. We use these alternative assessments as a robustness test and re-run our main analysis (findings hold, see Table S3 in the supplementary material).
} 
years in office). ${ }^{13}$ Based on this information we construct a dummy variable which captures the presence (1) or absence (0) of a populist chief executive in each year (at t-1 year) as the main independent variable in our models below.

\section{Moderating Factors}

To account for the potential moderating effect of the quality of each democratic model (H6) we include a lagged (dependent) variable of the level of each model of democracy (at t-1 year) in our estimations below. We discuss the methodological implications of the inclusion of a lagged dependent variable in more detail below.

Moreover, to account for the ideological leaning of each chief executive, in the European sample, we rely on the coding from Rooduijn et al. (2019) which groups political parties into radical left, radical right or centrist on a classical left-to-right spectrum. Note that the category "centrist" is very broad and includes both moderately ideological par- ties on both sides of the spectrum, genuinely centrist parties as well as non-ideological parties. To mirror this coding logic for Latin American cases, we use data from Murillo et al. (2010) which provides measures on the political ideology of presidents and par- ties on a fi e-point scale from left-to-right. We recode the measure into three categories (collapsing centre-left, centre, and centre-right cases into one category). We expand the coding until 2018. This leaves us with a three-categorical variable, which allows us to best approximate the inclusiveness or exclusiveness of both populist and non-populist political actors.

\section{Control Variables}

We include covariates to control for potential other effects on the level of democracy. As most researchers believe economic variables are connected to autocratization (Haggard \& Kaufman, 2016), GDP per capita and GDP per capita growth are included. The data on GDP per capita levels and growth (in 2011 USD and corrected for inflation were collected from the Maddison Project Database (Bolt et al., 2018). We use the logged version of both GDP per capita measures to account for exponential growth. Furthermore, we include a variable on economic gains from oil production as a control, accounting for arguments concerning a negative relationship between an oil-based economy and democracy (Ross, 2001; The World Bank,

13 In line with the coding of consecutive presidential terms in our data set on Latin America, we combine consecutive terms of prime ministers even if the cabinet composition changed over time. Non-consecutive terms interrupted by other presidents or prime ministers count as separate tenure episodes (e.g. Orbán 1998-2002 and 2010-2018). 
2019). ${ }^{14} 14$ We also account for the length of each chief executive's tenure, as leaders who stay in office longer are more likely to engage in erosive behaviour such as attempting to perpetuate their hold on power beyond legal terms (e.g. Corrales, 2016; Vencovsky, 2007). Moreover, several studies suggest a relationship between economic inequality and democratic backsliding due to, among other things, a translation of individual economic anxiety into politics and an increased demand for a 'strong' leader (Galston, 2019; Haggard \& Kaufman, 2016; Mudde \& Rovira Kaltwasser, 2018). To control for economic inequality we use Gini data on disposable income from the Standardized World Income Inequality Database (SWIID; Solt, 2016), which runs from 0 to 100 , with high values indicating more inequality. All of these control variables enter our models as a one-year lagged version ( $\mathrm{t}-1)$.

\section{Methods}

Our estimations are based on time-series cross-sectional data, covering 47 European and Latin American countries from 1995-2018 ( $\mathrm{n}=1115)$. We estimate fixed-effects models with both country- and time-fixed effects to gauge the yearly impact of populist governments on the level of different models of democracy. While country-fixed effects allow us to account for unobserved heterogeneity between different countries in our sample, we include time-fixed effects to account for unobserved shocks that hit all our countries equally during our observation period (see Allison, 2009). Moreover, we estimate cluster-robust standard errors to account for within group correlation of the error term (see Cameron \& Miller, 2015; Cameron \& Trivedi, 2005). ${ }^{15}$

Since we assume that the impact of populist governments on different models of democracy depends on previous levels of democracy, we include a lagged dependent variable in each of our models (with a t-1 lag structure) (Keele \& Kelly, 2006). We opt for this dynamic model specification mainly for substantive reasons. To account for the potential bias resulting from the inclusion of a lagged dependent variable in fixed-eff models (Nickell, 1981), we provide alternative model specifications with panel-corrected standard errors in the supplement (see Beck \& Katz, 1995, 1996, as well as Table S4a/b in the supplementary material). The results are remarkably robust with respect to our main findings - we will refer to deviations based on model specification

\footnotetext{
${ }^{14}$ As a robustness check we also ran models which control for the level of globalization, since there are theories that link globalization to support for populism. Therefore, we use the Konjunkturforschungsstelle (KOF) globalization indicator, which runs from 0 to 100 with high values indicating more globalization. Furthermore, as another robustness check we include a variable on corruption, as corruption is known to weaken democratic institutions (Diamond, 2008) and lower the support for democracy (Anderson \& Tverdova, 2003). We refrain from reporting these models in the manuscript due to issues of multi- collinearity. The results remain essentially the same in effect size, direction and level of significance. Results are available upon request from the authors.

${ }^{15} \mathrm{We}$ also performed Hausmann tests, which indicate that fixed-effects estimations are preferable to random-effects in all our models (see Greene, 2008).
} 
in the interpretation below.

\section{Results and Discussion}

This paper aims to study to what extent populist-led governments alter the quality of democracy during their rule in different ways (testing Hypotheses 1 through 5). Moreover, according to our theoretical expectations, we hypothesize that the impact of populism may be moderated by two factors: the strength of democracy prior to the rise of populists and the ideological leaning of governments (Hypothesis 6 and $7 \mathrm{a} / \mathrm{b}$ ). Therefore, in Table 2a we report both the non-conditional and in Table $2 \mathrm{~b}$ the conditional model for each of our dependent variables (i.e. the different V-Dem indices). The former aims at gauging the direct partial effect of populism (testing H1-H5), while the latter aims at capturing the moderating influence on this effect by previous levels of democracy (testing H6). In addition, Figure 3 shows the average marginal effects of populism on diff $t$ democratic models across varying levels of democracy (Brambor et al., 2006). Finally, to capture the moderating effect of ideology on the impact of populism (H7a/b), we provide graphical results in Figure $4 .{ }^{16}$

Overall, despite mixed-theoretical expectations, our results suggest a rather negative impact of populism on a variety of models of democracy. Concerning the results from the nonconditional models (see Table 2a), the correlates of change in V-Dem's Electoral Democracy Index (EDI), Model 1a in Table 2a, indicate that a populist-led government is associated with a statistically significant $(\mathrm{p}<0.05)$ average decrease of the EDI of 0.018 points per year $(\mathrm{se}=0.006)$. This is equivalent to a yearly 1.8 percent decrease of the index, which runs on a $0-1$ scale. This implies that during a 5-year term of populist rule the level of Electoral Democracy is predicted to decrease by 9 percent. Thus, the predicted negative effect is substantially meaningful. Based on our theory we were expecting mixed effects of populism on electoral democracy (H1); however, our results suggest that the balance tilts more in the negative direction.

Table 2a: Populism and Democracy in 47 Countries (1995-2018) - Unconditional Models

\begin{tabular}{|c|c|c|c|c|c|}
\hline & $\begin{array}{c}\text { Electoral } \\
\text { Democracy } \\
\text { Index } \\
\text { M1a }\end{array}$ & $\begin{array}{c}\text { Liberal } \\
\text { Component } \\
\text { Index } \\
\text { M2a }\end{array}$ & $\begin{array}{c}\text { Deliberative } \\
\text { Component } \\
\text { Index } \\
\text { M3a }\end{array}$ & $\begin{array}{c}\text { Participatory } \\
\text { Component } \\
\text { Index } \\
\text { M4a }\end{array}$ & $\begin{array}{c}\text { Egalitarian } \\
\text { Component } \\
\text { Index } \\
\text { M5a }\end{array}$ \\
\hline Populist PM/PR & $\begin{array}{c}-0.018^{* *} \\
(0.006)\end{array}$ & $\begin{array}{c}-0.018^{* *} \\
(0.006)\end{array}$ & $\begin{array}{l}-0.018 \\
(0.011)\end{array}$ & $\begin{array}{l}-0.003 \\
(0.004)\end{array}$ & $\begin{array}{l}-0.000 \\
(0.004)\end{array}$ \\
\hline
\end{tabular}

\footnotetext{
${ }^{16}$ Fixed-effects regression results for the conditional models with ideology are reported in Table S5 in the supplement.
} 


\begin{tabular}{|c|c|c|c|c|c|}
\hline Far-Left & $\begin{array}{l}-0.004 \\
(0.009)\end{array}$ & $\begin{array}{c}0.003 \\
(0.009)\end{array}$ & $\begin{array}{c}0.000 \\
(0.016)\end{array}$ & $\begin{array}{c}0.001 \\
(0.006)\end{array}$ & $\begin{array}{c}0.005 \\
(0.007)\end{array}$ \\
\hline Far-Right & $\begin{array}{l}-0.005 \\
(0.004)\end{array}$ & $\begin{array}{c}0.003 \\
(0.004)\end{array}$ & $\begin{array}{c}0.004 \\
(0.007)\end{array}$ & $\begin{array}{l}-0.005 \\
(0.004)\end{array}$ & $\begin{array}{l}-0.003 \\
(0.004)\end{array}$ \\
\hline EDI (V-Dem) & $\begin{array}{c}0.872^{* * *} \\
(0.030)\end{array}$ & & & & \\
\hline \multicolumn{6}{|l|}{ Pop*EDI } \\
\hline LCI (V-Dem) & & $\begin{array}{c}0.877^{* * *} \\
(0.018)\end{array}$ & & & \\
\hline \multicolumn{6}{|l|}{ Pop*LCI } \\
\hline DCI (V-Dem) & & & $\begin{array}{c}0.842^{* * *} \\
(0.041)\end{array}$ & & \\
\hline \multicolumn{6}{|l|}{ Pop*DCI } \\
\hline PCI (V-Dem) & & & & $\begin{array}{c}0.853^{* * *} \\
(0.026)\end{array}$ & \\
\hline \multicolumn{6}{|l|}{ Pop*PCI } \\
\hline ECI (V-Dem) & & & & & $\begin{array}{l}0.739^{* * *} \\
(0.045)\end{array}$ \\
\hline \multicolumn{6}{|l|}{ Pop*ECI } \\
\hline GDP/capita (log) & $\begin{array}{l}-0.001 \\
(0.005)\end{array}$ & $\begin{array}{l}-0.003 \\
(0.007)\end{array}$ & $\begin{array}{l}-0.007 \\
(0.011)\end{array}$ & $\begin{array}{c}0.010 \\
(0.008)\end{array}$ & $\begin{array}{l}-0.010 \\
(0.007)\end{array}$ \\
\hline GDP growth (log) & $\begin{array}{c}0.000 \\
(0.000)\end{array}$ & $\begin{array}{c}0.000 \\
(0.000)\end{array}$ & $\begin{array}{c}0.000 \\
(0.001)\end{array}$ & $\begin{array}{c}0.000 \\
(0.000)\end{array}$ & $\begin{array}{c}0.000 \\
(0.000)\end{array}$ \\
\hline Oil rent/GDP & $\begin{array}{l}-0.001^{+} \\
(0.001)\end{array}$ & $\begin{array}{l}-0.002 \\
(0.002)\end{array}$ & $\begin{array}{c}0.001 \\
(0.001)\end{array}$ & $\begin{array}{c}0.001 \\
(0.001)\end{array}$ & $\begin{array}{c}0.000 \\
(0.001)\end{array}$ \\
\hline Economic & -0.000 & 0.000 & 0.001 & 0.000 & -0.000 \\
\hline Inequality & $(0.000)$ & $(0.001)$ & $(0.001)$ & $(0.001)$ & $(0.001)$ \\
\hline Tenure duration & $\begin{array}{l}-0.001 \\
(0.000)\end{array}$ & $\begin{array}{l}-0.001^{+} \\
(0.000)\end{array}$ & $\begin{array}{l}-0.000 \\
(0.001)\end{array}$ & $\begin{array}{l}-0.000 \\
(0.000)\end{array}$ & $\begin{array}{l}-0.000 \\
(0.000)\end{array}$ \\
\hline Constant & $\begin{array}{c}0.116^{+} \\
(0.063)\end{array}$ & $\begin{array}{c}0.134^{+} \\
(0.073)\end{array}$ & $\begin{array}{c}0.154 \\
(0.118)\end{array}$ & $\begin{array}{l}-0.016 \\
(0.076)\end{array}$ & $\begin{array}{l}0.297^{* *} \\
(0.089)\end{array}$ \\
\hline NxT & 1115 & 1115 & 1115 & 1115 & 1115 \\
\hline Countries & 47 & 47 & 47 & 47 & 47 \\
\hline Years (avg.) & 23.72 & 23.72 & 23.72 & 23.72 & 23.72 \\
\hline adj. $R^{2}$ (within) & 0.84 & 0.85 & 0.71 & 0.73 & 0.55 \\
\hline Rho & 0.31 & 0.39 & 0.38 & 0.25 & 0.85 \\
\hline BIC & -5230.76 & -4922.89 & -3662.88 & -5448.29 & -5012.00 \\
\hline
\end{tabular}

Notes: ${ }^{+} p<0.10,{ }^{*} p<0.05,{ }^{* *} p<0.01,{ }^{* * *} p<0.001$; Fixed-effects models with clustered standard errors in parentheses; Time-fixed effects included but not reported; Reference category for extreme left/right is centrist/non-ideological.

The picture is similarly dire, when looking at the predicted effect of a year of populist rule on the Liberal Component Index (Model 2a). Again, we estimate an average annual decline of 1.6 percent on the V-Dem index, which is in line with our expectations (H2). In contrast, at least in our non-conditional models, we cannot support the expected negative effect on the quality of public debate and deliberation (Model 3a, H3), nor the expected positive association between 
populism and the models of participatory (Model 4a, H4) or egalitarian democracy (Model 5a, H5). While the coefficient in Model $3 \mathrm{a}$ - capturing the effect of populism on the V-Dem Deliberative Component Index - points in the expected direction, it does not reach conventional significance levels. However, in the conditional specification of the relationship between populism and deliberative democracy, we fi the expected negative relationship for medium and low levels of deliberation (see below as well as Figure 3c). Contrary to our expectations, Model 4a, which assesses the relationship of populism and the Participatory Component Index (PCI), estimates a negative, although statistically insignificant, relationship. Finally, Model 5a suggests that populism does not have the expected relationship to the egalitarian aspects of democracy either, as indicated by the negative sign of the coefficient. ${ }^{17}$

\section{Testing the role of the strength of democracy}

While these average effects are substantial and relevant, the question remains if populist's effect on democracy is conditional on the prior quality of the respective notion of democracy (H6). Therefore, we ran conditional models including the respective interaction terms (see Table $2 \mathrm{~b}$ ). The intuition here is that it might be more difficult for populists to undermine democracy in contexts with strong democratic institutions than in context with relatively weak democratic constraints (see Mudde \& Rovira Kaltwasser, 2012a; Schedler, 1998; Levitsky \& Murillo, 2013). Results in Table $2 \mathrm{~b}$ confirm this expectation at least for three models of democracy. More specifically, we fi statistically significant conditional effects with respect to the electoral, the liberal, and the deliberative model of democracy (Models 1b, 2b and 3b), substantiated by diff $\mathrm{t}$ goodness of fi measures (i.e. adj. R2 as well as BIC, see Table $2 \mathrm{~b}) .{ }^{18}$ We do not fi $\mathrm{d}$ any conditional effect for the participative or egalitarian models of democracy. To ease the interpretation of these results, Figure 3 reports the average marginal effects of populist-led governments at diff $t$ prior levels of the respective model of democracy. The figure illustrates that the effect of populist-led governments seems to become less severe with increasing levels of democracy and turns statistically insignificant above an EDI of about 0.85 , a LCI of about 0.85 or a DCI level of about $0.80 .^{19}$

\footnotetext{
${ }^{17}$ Most controls do not reach conventional levels of statistical significance even though they have been pointed out in prior literature as key correlates of regime change. This might partially be due to the set of cases under investigation (relatively advanced democracies) and the fixed-effects estimation strategy with a lagged dependent variable.

${ }^{18}$ In addition, F-tests indicate that the interaction term significantly increases the explanatory power for these three models as well.

${ }^{19}$ Above a level of the EDI as well as the DCI of about 0.95 , populism is predicted to even have a positive effect on the respective model of democracy. However, since we find no cases of populists taking power at such a high level of democracy in our sample, this prediction should be taken with a pinch of salt.
} 
Table 2b: Populism and Democracy in 47 Countries (1995-2018) - Conditional Models

\begin{tabular}{|c|c|c|c|c|c|}
\hline & $\begin{array}{l}\text { Electoral } \\
\text { Democracy } \\
\text { Index } \\
\text { M1b }\end{array}$ & $\begin{array}{l}\text { Liberal } \\
\text { Component } \\
\text { Index } \\
\text { M2b }\end{array}$ & $\begin{array}{l}\text { Deliberative } \\
\text { Component } \\
\text { Index } \\
\text { M3b }\end{array}$ & $\begin{array}{l}\text { Participatory } \\
\text { Component } \\
\text { Index } \\
\text { M4b }\end{array}$ & $\begin{array}{c}\text { Egalitarian } \\
\text { Component } \\
\text { Index } \\
\text { M5b }\end{array}$ \\
\hline Populist PM/PR & $-0.153^{* *}$ & $-0.118^{*}$ & $-0.208^{* *}$ & -0.047 & -0.015 \\
\hline Far-Left & $\begin{array}{c}(\mathbf{0 . 0 4 6 )} \\
-0.006 \\
(0.007)\end{array}$ & $\begin{array}{c}(\mathbf{0 . 0 4 5 )} \\
0.006 \\
(0.008)\end{array}$ & $\begin{array}{c}(\mathbf{0 . 0 6 6 )}) \\
0.004 \\
(0.011)\end{array}$ & $\begin{array}{l}(0.031) \\
-0.001 \\
(0.006)\end{array}$ & $\begin{array}{c}(0.021) \\
0.005 \\
(0.007)\end{array}$ \\
\hline Far-Right & $\begin{array}{l}-0.012^{*} \\
(0.005)\end{array}$ & $\begin{array}{l}-0.002 \\
(0.005)\end{array}$ & $\begin{array}{l}-0.001 \\
(0.007)\end{array}$ & $\begin{array}{l}-0.006 \\
(0.004)\end{array}$ & $\begin{array}{l}-0.004 \\
(0.004)\end{array}$ \\
\hline EDI (V-Dem) & $\begin{array}{c}0.757^{* * *} \\
(0.065)\end{array}$ & & & & \\
\hline Pop*EDI & $\begin{array}{l}0.179^{* *} \\
(0.055)\end{array}$ & & & & \\
\hline LCI (V-Dem) & & $\begin{array}{c}0.779^{* * *} \\
(0.045)\end{array}$ & & & \\
\hline Pop*LCI & & $\begin{array}{c}0.131^{*} \\
(0.055)\end{array}$ & & & \\
\hline DCI (V-Dem) & & & $\begin{array}{c}0.715^{* * *} \\
(0.065)\end{array}$ & & \\
\hline Pop*DCI & & & $\begin{array}{l}0.242^{* *} \\
(0.074)\end{array}$ & & \\
\hline PCI (V-Dem) & & & & $\begin{array}{c}0.830^{* * * *} \\
(0.028)\end{array}$ & \\
\hline Pop*PCI & & & & $\begin{array}{c}0.071 \\
(0.046)\end{array}$ & \\
\hline ECI (V-Dem) & & & & & $\begin{array}{c}0.735^{* * *} \\
(0.043)\end{array}$ \\
\hline Pop*ECI & & & & & $\begin{array}{c}0.021 \\
(0.028)\end{array}$ \\
\hline GDP/capita (log) & $\begin{array}{l}-0.002 \\
(0.006)\end{array}$ & $\begin{array}{l}-0.006 \\
(0.008)\end{array}$ & $\begin{array}{l}-0.007 \\
(0.012)\end{array}$ & $\begin{array}{c}0.009 \\
(0.008)\end{array}$ & $\begin{array}{l}-0.010 \\
(0.007)\end{array}$ \\
\hline GDP growth (log) & $\begin{array}{c}0.000 \\
(0.000)\end{array}$ & $\begin{array}{c}0.000 \\
(0.000)\end{array}$ & $\begin{array}{c}0.000 \\
(0.001)\end{array}$ & $\begin{array}{c}0.000 \\
(0.000)\end{array}$ & $\begin{array}{c}0.000 \\
(0.000)\end{array}$ \\
\hline Oil rent/GDP & $\begin{array}{c}-0.001^{+} \\
(0.001)\end{array}$ & $\begin{array}{c}-0.001 \\
(0.002)\end{array}$ & $\begin{array}{c}0.001 \\
(0.001)\end{array}$ & $\begin{array}{c}0.000 \\
(0.001)\end{array}$ & $\begin{array}{c}0.000 \\
(0.001)\end{array}$ \\
\hline Economic & -0.000 & -0.000 & 0.001 & 0.000 & -0.000 \\
\hline $\begin{array}{l}\text { Inequality } \\
\text { Tenure duration }\end{array}$ & $\begin{array}{l}(0.001) \\
-0.000 \\
(0.000)\end{array}$ & $\begin{array}{l}(0.001) \\
-0.000 \\
(0.000)\end{array}$ & $\begin{array}{c}(0.001) \\
0.000 \\
(0.001)\end{array}$ & $\begin{array}{c}(0.001) \\
-0.000 \\
(0.000)\end{array}$ & $\begin{array}{l}(0.001) \\
-0.000 \\
(0.000)\end{array}$ \\
\hline Constant & $\begin{array}{c}0.231^{*} \\
(0.087)\end{array}$ & $\begin{array}{c}0.259^{*} \\
(0.098)\end{array}$ & $\begin{array}{l}0.270^{+} \\
(0.142)\end{array}$ & $\begin{array}{c}0.008 \\
(0.078)\end{array}$ & $\begin{array}{l}0.305^{* *} \\
(0.087)\end{array}$ \\
\hline $\mathrm{NxT}$ & 1115 & 1115 & 1115 & 1115 & 1115 \\
\hline Countries & 47 & 47 & 47 & 47 & 47 \\
\hline Years (avg.) & 23.72 & 23.72 & 23.72 & 23.72 & 23.72 \\
\hline adj. $R^{2}$ (within) & 0.85 & 0.85 & 0.72 & 0.73 & 0.55 \\
\hline Rho & 0.54 & 0.59 & 0.49 & 0.28 & 0.85 \\
\hline BIC & -5298.52 & -4973.03 & -3716.18 & -5447.35 & -5006.16 \\
\hline
\end{tabular}

Notes: ${ }^{+} p<0.10,{ }^{*} p<0.05,{ }^{* *} p<0.01,{ }^{* * *} p<0.001$; Fixed-effects models with clustered standard errors in parentheses; Time-fixed effects included but not reported; Reference category for extreme left/right is centrist/non-ideological. 


\section{Figure 3: Marginal Effect of Populism Conditioned by Quality of Democracy}

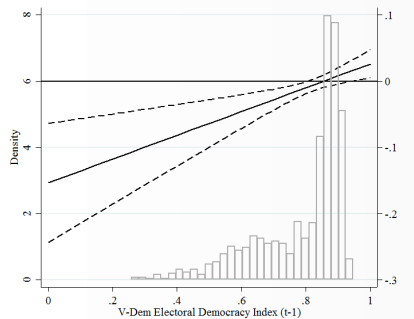

(a)

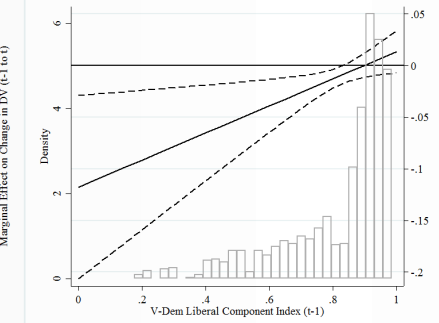

(b)

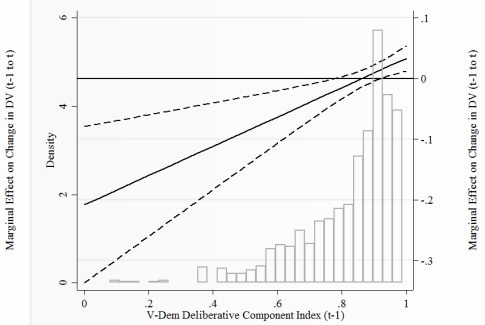

(c)

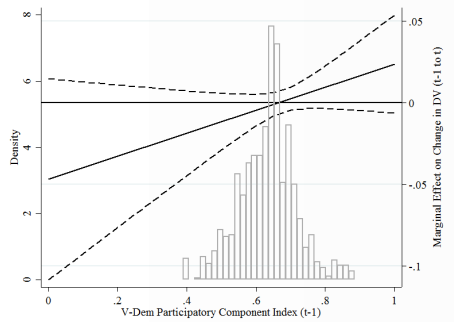

(d)

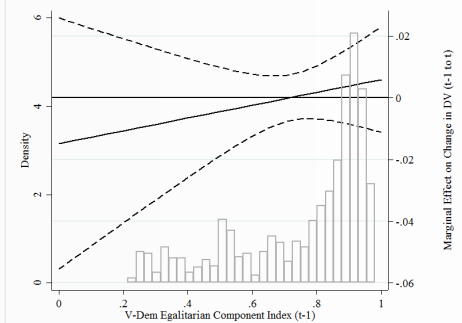

(e)

\section{Testing the role of ideology}

In order to analyse the potentially divergent effect of far-left and far-right populist governments on different models of democracy, we ran further analyses including an additional interaction between our binary populism variable and a three-categorical ideological variable. To ease interpretation, Figure 4 plots the marginal effects of populism across different ideological sub-groups. Although these graphs indicate interesting patterns, most of them do not reach conventional significance levels, which is probably largely due to the small number of observations in each group. ${ }^{20}$ Test statistics only support the additional inclusion of an interaction term between populism and ideology for the model testing the associations with the Electoral Democracy Index (detailed results are reported in Table S5 in the supplement). In contrast to our expectations, the interaction indicates that ideology rather moderates the effect of non-populist governments on levels of electoral democracy. While far-left non-populist governments are associated with a significant in- crease in levels of electoral democracy, far-right non-populist governments significantly decrease the level of electoral democracy. The former findings resonates with arguments made in the literature about the two lefts in Latin America - the good (social-

\footnotetext{
${ }^{20}$ In our sample we have 93 country-years of far-right-led governments of which only 17 are populist (Hungary 2010- 2018; Panama 1999-2003; and Poland 2005 and 2015-2018). During 60 years, countries were led by far-left governments of which 49 years were populist-led (e.g. Bolivia 2006-2018; Greece 2015-2018; and Venezuela 19992018).
} 
democratic) left and the bad (populist) left (Levitsky \& Roberts, 2011; Roberts, 2007; Weyland, 2009). With respect to populism, graphical results indicate several interesting patterns. For one, Figure 4 confirms the negative association between populism and levels of electoral and liberal democracy reported in Table $2 \mathrm{a}$ - and indicates that this association seems to be driven by both far-right and far-left populist governments. With respect to Hypothesis $7 \mathrm{a}$ - which posits a negative effect of far-right populism on deliberative democracy - the pattern in the upper right panel of Figure 4 does not confirm our expectation. Concerning Hypothesis $7 \mathrm{~b}-$ which states a positive effect of far-left populism on egalitarian democracy - the pattern in the lower right panel of Figure 3 points in the expected direction, but falls short of conventional significance levels. These non-findings may in part be due to the relatively small sample and the restrictive focus on extreme ideological leanings on the far-right or far-left. Future research will need to factor in ways to capture more fine grained distinctions with respect to the inclusiveness or exclusiveness of nonpopulist and populist governments alike.

Overall, it is important to note that the negative relationship between populism and electoral, liberal, as well as deliberative democracies holds even if we control for far-right and farleft populist variants.

Figure 4: Marginal Effect of Populism Conditioned by Ideology

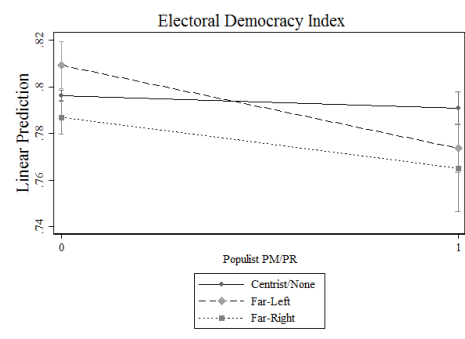

(a)

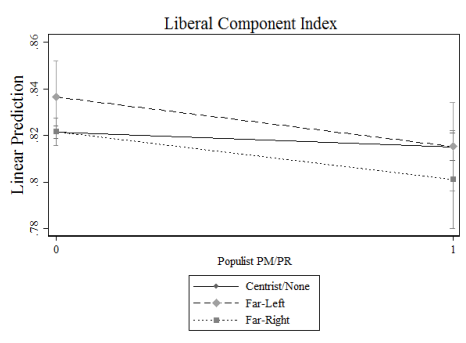

(b)

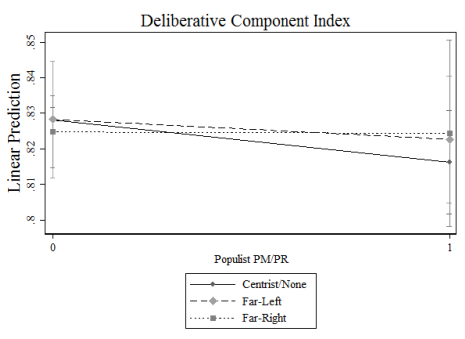

(c)

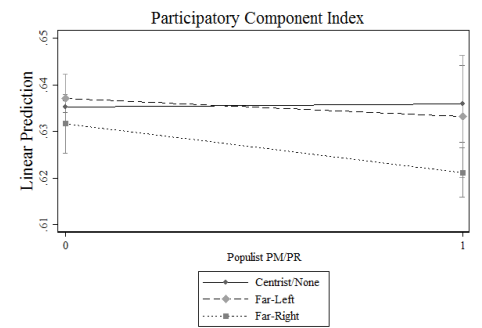

(d)

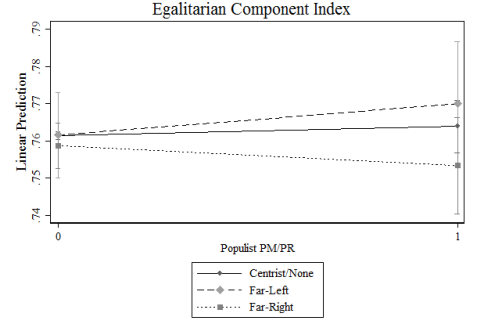

(e) 


\section{Conclusion and Way Forward}

The relationship between populism and democracy has puzzled researchers for decades, most importantly, the potential negative and positive consequences populism may have on diff $\mathrm{t}$ aspects of democracy (e.g. Mény \& Surel, 2002; Mudde \& Rovira Kaltwasser, 2012a; Rovira Kaltwasser, 2012). With this paper we add to a growing body of empirical work on this matter. Moving beyond the dominant fragmented perspective in the literature, we investigate the relationship between populism and democracy within an integrated framework and in two world regions particularly affected by populism in government - Europe and Latin America (Aslanidis, 2017; Mudde \& Rovira Kaltwasser, 2018). Moreover, responding to Wolff's (2018) plea that research on the patterns of backsliding and autocratization should not only focus on electoral and liberal aspects of democracy, we explicitly consider potentially positive developments in terms of egalitarianism and participation. Therefore, we investigate the relationship between populist governments and fi e democratic models: electoral, liberal, deliberative, egalitarian and participatory democracy.

Our results indicate that, on average, populist governments tend to erode the level of the electoral, liberal and deliberative model of democracy. At the same time, however, we were not able to corroborate any positive relationship of populist-led governments with respect to egalitarian or participatory aspects of democracy.

Our empirical analysis provides clear evidence that the consequence of populist governments is not a decoupling of liberalism and democracy. Rather, what we are seeing under some populist governments is a decline of liberalism, deliberation and the electoral core of democracy. At the same time, populist governments do not live up to their promise of substantially improving and rejuvenating democracy as indicated by the absence of positive changes on the democracy indices. On a more optimistic note, our results indicate that more mature democracies are less prone to the deteriorating effects of populist rule. Confirming previous arguments, the negative consequences of populism are moderated by previously higher levels of electoral, liberal and deliberative democratic institutions (Mudde \& Rovira Kaltwasser, 2012a). Finally, our results indicate that the erosive potential of populist rule holds on both sides of the ideological spectrum. Even when controlling for extreme left or right ideology, we fi negative and significant effects of populism on the three models of democracy reported above.

While our analyses provides first insights into the multi-dimensional effects of populism on different facets of democracy, both across regions and time, much more remains to be done. Future research needs to dig deeper into which aspects of the respective models of democracy are affected the most by populist rule - this way we might even uncover the theoretically expected 
associations between populism and participatory and egalitarian models of democracy. Moreover, a more fine grained coding of the ideological leaning of populist and non-populism governments could yield further insight into the role of ideology as a moderating factor. Finally, while our focus was on the major political players in a political system - chief executives - future research needs to factor in the consequences of populism in opposition as well. 


\section{References}

Albertazzi, D., \& McDonnell, D. (2008). Introduction: The sceptre and the spectre. In D. Albertazzi \& D. McDonnell (Eds.), Twenty-first century populism: The spectre of Western European democracy (pp. 1-11). London: Palgrave Macmillan UK.

Allison, P. D. (2009). Fixed effects regression models. Thousand Oaks: SAGE Publications.

Anderson, C. J., \& Tverdova, Y. V. (2003). Corruption, political allegiances, and attitudes toward government in contemporary democracies. American Journal of Political Science, 47 (1), 91-109.

Aslanidis, P. (2016). Is populism an ideology? A refutation and a new perspective. Political Studies, 64 (IS), 88-104.

Aslanidis, P. (2017). Avoiding bias in the study of populism. Chinese Political Science Review, 2 (3), 266-287.

Aslanidis, P. (2018). Measuring populist discourse with semantic text analysis: an application on grassroots populist mobilization. Quality \& Quantity, 52 (3), 1241-1263.

Batory, A. (2016). Populists in government? Hungary's "system of national cooperation". Democratization, 23 (2), 283-303.

Beck, N., \& Katz, J. N. (1995). What to do (and not to do) with time-series cross-section data. American Political Science Review, 89 (03), 634-647.

Beck, N., \& Katz, J. N. (1996). Nuisance vs. substance: Specifying and estimating time-seriescross-section models. Political Analysis, 6 (1), 1-36.

Bogaards, M. (2018). De-democratization in Hungary: Diff defective democracy. Democratization, 25 (8), 1481-1499.

Bolt, J., Inklaar, R., de Jong, H., \& Luiten van Zanden, J. (2018). Maddison project database, version 2018. Rebasing 'Maddison': new income comparisons and the shape of long-run economic development. Maddison project working paper 10.

Bonikowski, B. (2017). Ethno-nationalist populism and the mobilization of collective resentment. The British Journal of Sociology, 68 (S1), S181-S213.

Bowler, S., Donovan, T., \& Karp, J. A. (2007). Enraged or engaged? preferences for direct citizen participation in affluent democracies. Political Research Quarterly, 60 (3), 351-362.

Brambor, T., Clark, W. R., \& Golder, M. (2006). Understanding interaction models: Improving empirical analyses. Political Analysis, 14, 63-82.

Cameron, C. A., \& Miller, D. L. (2015). A practitioner's guide to cluster-robust inference. Journal of Human Resources, 50 (2), 317-372.

Cameron, C. A., \& Trivedi, P. (2005). Microeconometrics. Cambridge: Cambridge University Press.

Canovan, M. (1982). Two strategies for the study of populism. Political Studies, 30 (4), 544-552.

Canovan, M. (1999). Trust the people! populism and the two faces of democracy. Political Studies, $47(1), 2-16$.

Canovan, M. (2002). Taking politics to the people: Populism as the ideology of democracy. In Y. M'eny \& Y. Surel (Eds.), Democracies and the populist challenge (p. 25-43). New York: Palgrave.

Caramani, D. (2017). Will vs. reason: The populist and technocratic forms of political representation and their critique to party government. American Political Science Review, 111 (1), 54-67.

Chesterley, N., \& Roberti, P. (2018). Populism and institutional capture. European Journal of Political Economy, 53, 1-12.

Collier, D., \& Levitsky, S. (1997). Democracy with adjectives: Conceptual innovation in comparative research. World Politics, 49 (3), 430-451.

Conniff, M. L. (2012). Populism in Latin America (Second edition). Tuscaloosa: The University of Alabama Press. 
Coppedge, M., Gerring, J., Altman, D., Bernhard, M., Fish, S., Hicken, A., . . Teorell, J. (2011). Conceptualizing and measuring democracy: A new approach. Perspectives on Politics, 9 (2), 247267.

Coppedge, M., Gerring, J., Knutsen, C. H., Lindberg, S., Teorell, J., Marquardt, K., . . Wilson, S. (2019). V-dem methodology v9. Varieties of Democracy (V-Dem) Project.

Coppedge, M., Gerring, J., Knutsen, C. H., Lindberg, S. I., Skaaning, S.-E., Teorell, J.,. . Z Ziblatt, D. (2019). V-dem codebook v9. Varieties of Democracy (V-Dem) Project

Coppedge, M., Lindberg, S., Skaaning, S.-E., \& Teorell, J. (2015). Measuring high level democratic principles using the v-dem data. International Political Science Review, 37 (5), 580-593.

Corrales, J. (2016). Can anyone stop the president? power asymmetries and term limits in latin america, 1984-2016. Latin American Politics and Society, 58 (2), 3-25.

Dahl, R. A. (1956). A preface to democratic theory. Chicago and London: University of Chicago Press.

Dahl, R. A. (1971). Polyarchy: Participation and opposition. New Haven: Yale University Press.

Dahl, R. A. (1989). Democracy and its critics. New Haven, CT: Yale University Press.

Decker, F. (2011). Demokratischer populismus und/oder populistische demokratie? Bermerkungen zu einem schwierigen verhaltnis. In F. Wielenga \& F. Hartleb (Eds.), Populismus in der modernen demokratie - die niederlande und deutschland im vergleich (p. 39-54). Mu"nster: Waxmann Verlag.

De Cleen, B., \& Stavrakakis, Y. (2017). Distinctions and articulations: A discourse theoretical framework for the study of populism and nationalism. Javnost - The Public, 24 (4), 301-319.

Diamond, L. (2008). The democratic rollback. the resurgence of the predatory state. Foreign Affairs, 87 (2), 36-48.

Dryzek, J. S. (2010). Foundations and frontiers of deliberative governance. Oxford: Oxford University Press.

Dubiel, H. (1986). Populismus und aufklarung. Frankfurt am Main: Suhrkamp.

Fishkin, J. S. (1991). Democracy and deliberation: New directions for democratic reform. New Haven: Yale University Press.

Foweraker, J. (2018). Polity. Demystifying democracy in Latin America and beyond. Boul- der, London: Lynne Rienner Publishers.

Fung, A., \& Wright, E. O. (2003). Deepening democracy. institutional innovations in empowered participatory governance. London: Verso.

Galston, W. A. (2019). The populist challenge to liberal democracy. Journal of Democracy, 29 (2), 5 19.

Giebler, H., \& Merkel, W. (2016). Freedom and equality in democracies: Is there a trade-off? International Political Science Review, 37 (5), 594-605.

Greene, W. H. (2008). Econometric analysis. Upper Saddle River, N.J.: Prentice Hall.

Grofman, B., \& Feld, S. L. (2013). Rousseau's general will: A condorcetian perspective. American Political Science Review, 82 (2), 567-576.

Habermas, J. (1992). Faktiqitat und geltung: Beitrage zur diskurtstheorie des rechts und des demokratischen rechtsstaats. Frankfurt am Main: Surhkamp.

Haggard, S., \& Kaufman, R. R. (2016). Dictators and democrats. masses, elites and regime change. Princeton, NJ: Princeton University Press.

Hartleb, F. (2017). Die stunde der populisten - wie sich unsere politik trumpisiert und was wir dagegen tun konnen. Schwalbach Ts.: Wochenschau Verlag.

Hawkins, K. A. (2010). Venezuela's chavismo and populism in comparative perspective. Cambridge: Cambridge University Press.

Hawkins, K. A., Carlin, R. E., Littvay, L., \& Rovira Kaltwasser, C. (2019). The ideational approach to populism. Concept, theory, and analysis. London: Routledge.

Hawkins, K. A., \& Rovira Kaltwasser, C. (2017). The ideational approach to populism. Latin 
American Research Review, 52 (4), 513-528.

Held, D. (2010). Models of democracy. Cambridge: Polity Press.

Houle, C., \& Kenny, P. D. (2018). The political and economic consequences of populist rule in Latin America. Government and Opposition, 53 (2), 256-287.

Huber, R. A., \& Ruth, S. P. (2017). Mind the gap! Populism, participation, and representation in Europe. Swiss Political Science Review, 23 (4), 462-484.

Huber, R. A., \& Schimpf, C. H. (2016). A drunken guest in europe? Zeitschrift fur Vergleichende Politikwissenschaft, 10 (2), 103-129.

Huber, R. A., \& Schimpf, C. H. (2017). On the distinct effects of left-wing and right-wing populism on democratic quality. Politics and Governance, 5 (4), 146-165.

Inglehart, R., \& Norris, P. (2017). Trump and the populist authoritarian parties: The silent revolution in reverse. Perspectives on Politics, 15 (2), 443-454.

Keane, J. (2009). The life and death of democracy. London: Pocket Books.

Keele, L., \& Kelly, N. J. (2006). Dynamic models for dynamic theories: The ins and outs of lagged dependent variables. Political Analysis, 14 (2), 186-205.

Kenny, P. D. (2019). "The enemy of the people": Populists and press freedom. Political Research Quarterly. (Online: https://doi.org/10.1177/1065912918824038)

Laclau, E. (2005). On populist reason. London: Verso.

Laclau, E., \& Mouffe, C. (1985). Hegemony and socialist strategy: Towards a radical democratic politics. London: Verso.

Levitsky, S., \& Loxton, J. (2013). Populism and competitive authoritarianism in the Andes. Democratization, 20 (1), 107-136.

Levitsky, S., \& Murillo, M. V. (2013). Lessons from Latin America: Building institutions on weak foundations. Journal of Democracy, 24 (2), 93-107.

Levitsky, S., \& Roberts, K. M. (2011). The resurgence of the Latin American left. Baltimore: The Johns Hopkins University Press.

Lijphart, A. (1999). Patterns of democracy. government forms and performance in thirty- six countries. New Haven, London: Yale University Press.

Mair, P. (2009). Representative versus responsible government. (MPIfG Working Paper, No. 09/8)

March, L. (2007). From vanguard of the proletariat to vox populi: Left-populism as a 'shadow' of contemporary socialism. SAIS Review, 27, 63-77.

Muller, J.-W. (2016). What is populism? Philadelphia: University of Pennsylvania Press.

M'eny, Y., \& Surel, Y. (2002). The constitutive ambiguity of populism. In Y. M'eny \& Y. Surel (Eds.), Democracies and the populist challenge (p. 1-21). New York: Palgrave.

Mudde, C. (2004). The populist zeitgeist. Government and Opposition, 39 (4), 541-563.

Mudde, C. (2007). Populist radical right parties in Europe. Cambridge: Cambridge University Press.

Mudde, C., \& Rovira Kaltwasser, C. (2012a). Populism and (liberal) democracy: a framework for analysis. In C. Mudde \& C. Rovira Kaltwasser (Eds.), Populism in Europe and the Americas. Threat or corrective for democracy? (p. 1-26). Cambridge: Cambridge University Press.

Mudde, C., \& Rovira Kaltwasser, C. (2012b). Populism in Europe and the Americas. Threat or corrective for democracy? Cambridge: Cambridge University Press.

Mudde, C., \& Rovira Kaltwasser, C. (2013). Exclusionary vs. inclusionary populism: Comparing contemporary Europe and Latin America. Government and Opposition, 48 (2), 147-174.

Mudde, C., \& Rovira Kaltwasser, C. (2018). Studying populism in comparative perspective: Reflections on the contemporary and future research agenda. Comparative Political Studies, 51 (13), 1667-1693.

Munck, G. L. (2016). What is democracy? a reconceptualization of the quality of democracy. Democratization, 23 (1), 1-26. 
Munck, G. L., \& Verkuilen, J. (2002). Conceptualizing and measuring democracy: Evaluating alternative indices. Comparative Political Studies, 35 (1), 5-34.

Murillo, M. V., Oliveros, V., \& Vaishnav, M. (2010). Dataset on political ideology of presidents and parties in Latin America. (Available at http://mariavictoriamurillo.com/data/ or http://www.virginiaoliveros.com/data/)

Nickell, S. (1981). Biases in dynamic models with fixed effects. Econometrica, 49 (6), 1417-1426.

Ochoa Espejo, P. (2012). Paradoxes of popular sovereignty: A view from Spanish America. The Journal of Politics, 74 (4), 1053-1065.

Ochoa Espejo, P. (2015). Power to whom? The people between procedure and populism. In C. De la Torre (Ed.), The promise and perils of populism. Global perspectives. (p. 59- 90). Lexington: The University Press of Kentucky.

O’Donnell, G. (1996). Illusions about consolidation. Journal of Democracy, 7 (2), 34-51.

O'Donnell, G. (2003). Horizontal accountability: The legal institutionalization of mistrust. In S. Mainwaring \& C. Welna (Eds.), Democratic accountability in Latin America (p. 33-54). Oxford: Oxford University Press.

Ostiguy, P. (2017). Populism: A socio-cultural approach. In C. Rovira Kaltwasser, P. Taggart, P. Ochoa Espejo, \& P. Ostiguy (Eds.), The oxford handbook of populism (p. 73-97). Oxford: Oxford University Press.

Pateman, C. (1976). Participation and democratic theory. Cambridge: Cambridge University Press.

Pateman, C. (2012). Participatory democracy revisited. Perspectives on Politics, 10 (1), 7-19.

Pemstein, D., Marquardt, K., Tzelgov, E., Wang, Y.-T., Krusell, J., \& Miri, F. (2018). The v-dem measurement model: Latent variable analysis for cross-national and cross- temporal expert-coded data (Tech. Rep. No. 21). University of Gothenburg. (Available at http://dx.doi.org/10.2139/ssrn.3167764)

Plattner, M. F. (1999). From liberalism to liberal democracy. Journal of Democracy, 10 (3), 121-134.

Plattner, M. F. (2010). Populism, pluralism, and liberal democracy. Journal of Democracy, 21 (1), 81 92.

Plattner, M. F. (2019). Illiberal democracy and the struggle on the right. Journal of Democracy, 1, 519.

Rhodes-Purdy, M. (2015). Participatory populism: Theory and evidence from Bolivarian Venezuela. Political Research Quarterly, 68 (3), 415-427.

Roberts, K. M. (2007). Latin America's populist revival. SAIS Review of International Affairs, 27 (1), 3-15.

Roberts, K. M. (2017). Populism and political parties. In C. Rovira Kaltwasser, P. Taggart, P. Ochoa Espejo, \& P. Ostiguy (Eds.), The oxford handbook of populism. Oxford: Oxford University Press.

Roberts, K. M. (2018). Left, right, and the populist structuring of political competition. In C. de la Torre (Ed.), Routledge bandbook of global populism (p. 149-162).

Rodrik, D. (2018). Populism and the economics of globalization. Journal of International Business Policy, 1 (1), 12-33.

Rooduijn, M. (2014a). The nucleus of populism: In search of the lowest common denominator. Government and Opposition, 49 (4), 573-599.

Rooduijn, M. (2014b). Vox populismus: a populist radical right attitude among the public? Nations and Nationalism, 20 (1), 80-92.

Rooduijn, M., \& Akkerman, T. (2017). Flank attacks: Populism and left-right radicalism in western europe. Party Politics, 23 (3), 193-204.

Rooduijn, M., Van Kessel, S., Frioio, C., Pirro, A., De Lange, S. L., Halikiopoulou, D., . . Taggart, P. (2019). The populist: An overview of populist, far right, far left and eurosceptic parties in Europe. (Available at http://www.popu-list.org) 
Ross, M. (2001). Does oil hinder democracy? World Politics, 53 (3), 325-361.

Rovira Kaltwasser, C. (2012). The ambivalence of populism: Threat and corrective for democracy. Democratization, 19 (2), 184-208.

Rovira Kaltwasser, C. (2014). The responses of populism to Dahl's democratic dilemmas. Political Studies, 62 (3), 470-487.

Rovira Kaltwasser, C., Taggart, P., Ochoa Espejo, P., \& Ostiguy, P. (2017). The oxford handbook of populism. Oxford: Oxford University Press.

Ruth, S. P. (2018). Populism and the erosion of horizontal accountability in Latin America. Political Studies, 66 (2), 356-375.

Ruth, S. P., \& Hawkins, K. A. (2017). Populism and democratic representation in Latin America. In C. Holtz-Bacha, O. Mazzoleni, \& R. Heinisch (Eds.), Handbook on political populism (p. 255273). Baden-Baden: Nomos.

Ruth, S. P., \& Welp, Y. (2018). Populism and direct democracy in Latin America. (Paper presented at the Latin American Studies Association, XXXVI International Congress, May 23-26, Barcelona (Spain))

Saward, M. (1998). The terms of democracy. New York: Polity Press.

Saward, M. (2000). Democratic innovation. deliberation, representation and association. London: Routledge.

Scharpf, F. W. (1999). Regieren in Europa: Effektiv und demokratisch? Frankfurt, New York: Campus Verlag.

Schedler, A. (1998). What is democratic consolidation? Joumal of Democracy, 9 (2), 91-107.

Schmidt, V. A. (2013). Democracy and legitimacy in the European Union revisited: Input, output and 'throughput'. Political Studies, 61 (1), 2-22.

Schumpeter, J. A. (1950). Capitalism, socialism and democracy. New York: Harper \& Brothers.

Shefner, J. (2013). What is politics for? inequality, representation, and needs satisfaction under clientelism and democracy. In T. Hilgers (Ed.), Clientelism in everyday Latin American politics (p. 41-59). Palgrave-MacMillan.

Solt, F. (2016). Standardizing the world income inequality database. Social Science Quarterly, 97 (5), 1267-1281.

The World Bank. (2019). World development indicators (Tech. Rep.). (Available at http://datatopics.worldbank.org/world-development-indicators/)

Urbinati, N. (1998). Democracy and populism. Constellations, 5 (1), 110-124.

Vencovsky, D. (2007). Presidential term limits in Africa. Conflict Trends, 2007 (2), 15-21.

Weyland, K. (2009). The rise of Latin America's two lefts: Insights from rentier state theory. Comparative Politics, 41 (2), 145-164.

Weyland, K. (2017). Populism: A political-strategic approach. In C. Rovira Kaltwasser, P. Taggart, P. Ochoa Espejo, \& P. Ostiguy (Eds.), The oxford handbook of populism (p. 48-72). Oxford: Oxford University Press.

Wolff, J. (2018). Political incorporation in measures of democracy: A missing dimension (and the case of Bolivia). Democratization, 25 (4), 692-708.

Zakaria, F. (1997). The rise of illiberal democracy. Foreign Affairs, 76 (6), 22-43. 